\title{
A Integração Asiática depois da Crise Financeira Global"
}

\section{Asia Integration after the Global Financial Crisis}

André Moreira Cunha**

Resumo: Desde o final dos anos 1990, a integração econômica regional e a ascensão da China têm sido duas forças marcantes na conformação da economia asiática. Este artigo avalia alguns dos impactos da crise financeira global em curso sobre aquela dinâmica, especialmente em suas dimensões monetária e financeira. Argumentamos que o cenário pós-crise se inclina para a consolidação da liderança chinesa e, como consequência, reforça a tendência de um processo de integração regional cada vez mais sino-cêntrico.

Palavras-chave: Crise financeira global. Integração asiática. China.

Abstract: Since late 1990s, regional economic integration and China's rise have been a major forces shaping Asia economy. Considering this background, this article evaluates some impacts of the current global financial crisis in that dynamics, particularly in the monetary and financial dimensions. We argue that the post crisis scenario is prone to the consolidation of China's economic and financial leadership, and as a consequence, to the reinforcement of a Sinocentric integration process.

Keywords: Global financial crisis. Asia integration. China.

JEL Classification: F36; F59.

\section{Introdução}

Uma década separa a eclosão de duas crises financeiras, cujas repercussões ainda se fazem sentir. Em 1997-1998, várias economias asiáticas sucumbiram diante da força desestabilizante dos fluxos de capitais em fuga. Potências emergentes, como a Coreia do Sul (somente Coreia, de

* $\quad$ Agradeço aos pertinentes comentários dos(as) pareceristas anônimos(as). Os erros e omissões restantes no texto são de exclusiva responsabilidade do autor. Agradeço, também, o apoio de pesquisa de Luíza Cardoso de Andrade, bolsista PIBIC-CNPq.

** Professor do Departamento de Economia da Universidade Federal do Rio Grande do Sul (UFRGS) e pesquisador do CNPq. E-mail: andre.cunha@ufrgs.br 
agora em diante), ou promessas de novos milagres, como Malásia, Indonésia, Tailândia e, com menor destaque, Filipinas, eram então percebidas como virtualmente imunes às crises financeiras derivadas de desequilíbrios macroeconômicos e institucionais típicos de economias periféricas. Dentre várias consequências, a crise asiática despertou nos países da região a consciência de sua interdependência e dos riscos derivados da globalização financeira. Iniciou-se um processo de crescente cooperação nas áreas monetária e financeira, comercial e de formação de uma infraestrutura institucional e física capaz de dar sustentação a uma dinâmica de crescente integração. Este novo impulso deu-se em meio a uma realidade distinta, em que é possível destacar pelo menos dois fenômenos: (i) a explicitação de um quadro de instabilidade estrutural, especialmente no período 1997-2002, com recorrentes episódios de crises financeiras para além do próprio caso asiático, como a moratória russa (1998), a quebra do fundo hedge Long Term Capital Management (1998), as crises brasileira (1999 e 2002) e argentina (2001-2002), a ruptura da bolha do setor de alta tecnologia e os escândalos corporativos nos EUA (20002002) que, em conjunto, impuseram importantes perdas patrimoniais aos detentores de ações, e uma série de outros episódios; e (ii) a ascensão da China à condição de potência econômica com projeções de poder em escala mundial, o que marcou o ciclo de crescimento global entre 2003 e começos de 2008, bem como determinou a face contemporânea rerregionalização asiática.

Em 2007-2008 eclodiu a crise financeira global, originada nas interações entre os mercados de crédito, especialmente imobiliário, dívidas estruturadas e derivativos, com profundas repercussões, reais e financeiras, sobre virtualmente todas as economias. Aquela, que tem sido apontada como a mais grave crise desde 1929, nasceu no núcleo da economia globalizada, os EUA. A insatisfação, até então impotente e dispersa, com o modelo de capitalismo dominado pelas finanças globalizadas e desregulamentadas, ganhou força suficiente para dar legitimidade política e intelectual aos críticos do Consenso de Washington, bem como cristalizou, no imaginário de muitos, o cenário de que o mundo pós-crise será diferente, com a intensificação da perda de poder relativos dos EUA, a ascensão de novas forças econômicas e políticas, e o retorno do Estado como ator de destaque (EL-ERIAN, 2008; SPENCE, 2009; GROSS, 2009).

É neste contexto que o presente artigo lança um olhar sobre a região mais dinâmica da economia global, a Ásia-Pacífico, para verificar alguns dos impactos potenciais da crise financeira global em curso. Mais especificamente, o trabalho questiona se a crise atual, assim como aquela verificada há uma década, dará novo impulso ao processo de integração 
regional, especialmente em sua dimensão monetária e financeira. A complexidade da questão e o fato de que os efeitos da crise ainda estão se fazendo sentir não permitem o desenho de uma resposta fechada. Por isso mesmo, busca-se contribuir com a análise deste relevante fenômeno, por meio da explicitação de uma hipótese de trabalho, qual seja: espera-se que, com a crise financeira global, as recentes tendências integracionistas aprofundem-se no sentido de exigir dos países uma maior coordenação e cooperação, com importantes desdobramentos nas esferas monetária e financeira. A consolidação da China como espaço cêntrico para a economia regional, em meio ao projeto de internacionalização de sua economia e, mais recentemente, de sua moeda, bem como a contestação à posição hegemônica do dólar estadunidense (somente dólar, de agora em diante) nas finanças internacionais sinalizam neste sentido.

Para desenvolver essa hipótese, os argumentos estão estruturados da seguinte forma: inicia-se com uma breve síntese da evolução da economia global nos anos que antecederam à crise e que, não por acaso, marcaram a ascensão chinesa à condição de potência global. Na sequência, mostra-se a dinâmica de integração regional asiática, com destaque para o período que se seguiu à crise de 1997-1998. Nas considerações finais, são analisados, brevemente, alguns efeitos da crise atual sobre a região. Os principais argumentos são retomados de modo a dar forma à nossa hipótese central, com a indicação de algumas evidências que lhe deem sustentação como um norte para futuras pesquisas.

\section{A Ascensão da China e a Economia Global}

Entre 2003 e 2008 (primeiro semestre), a economia mundial viveu um ciclo de expansão excepcionalmente favorável. Tal caráter excepcional deveu-se à confluência de alguns fatores, principalmente: crescimento elevado - com taxas médias de variação no PIB global acima de $4 \%$ associado à inflação baixa (pelo menos até meados de 2007); retomada de dinamismo em regiões que, nos anos 1980 e 1990, apresentaram níveis baixos de expansão da renda, tais como América Latina, África e Leste Europeu, ou em economias maduras como Japão e Alemanha; melhoria substancial nos resultados das contas externas e nas finanças públicas das economias em desenvolvimento previamente caracterizadas por níveis elevados de vulnerabilidade externa e fragilidade fiscal. ${ }^{1}$ Estas características brotaram em um momento em que a estrutura da economia revelava uma nova realidade: economias emergentes, como

1 Ver, entre outros, Toloui (2007), BIS (2007; 2008; 2009), Cepal (2008), IMF (2008a; 2009a), UNCTAD (2009). 
China, Índia, Rússia, Brasil, dentre outras, passaram a ter um peso na renda mundial, nos fluxos de comércio e na determinação do ritmo de expansão equivalentes ou superiores aos das economias centrais. Dados do FMI (2008a; 2009a) sugerem que, em 2007 e 2008, mais da metade do PIB global, medido em paridade de poder de compra, era gerado nos países em desenvolvimento.

De acordo com tais estimativas (IMF, 2008a e 2009a), a tendência de crescimento do PIB mundial foi se acelerando suavemente com o avanço da globalização, tendo, na primeira década do século XXI, um momento de auge. Por seu turno, entre 2003 e 2008, o PIB efetivo cresceu em média 4,4\% ao ano, bem acima da tendência. Com respeito ao comércio exterior, verificou-se o mesmo movimento. Este quadro, por si só, normalmente estaria associado a um processo de aceleração inflacionária, o que não ocorreu. Tanto para as economias avançadas quanto para as em desenvolvimento, os preços ao consumidor final mostraram-se bem-comportados, a despeito da sensível elevação dos preços reais (deflacionados) das matérias-primas nos anos recentes (UNCTAD, 2008, 2009). É bem verdade que, no caso dos países em desenvolvimento, a alta nos preços de alimentos e energia desdobrouse em aumento da inflação no ano de 2008.

Com explicar esta situação especial? Em grande medida, ela foi produzida pela convergência de fatores conjunturais e de uma transformação estrutural que, então, explicitou-se com muita intensidade. Do ponto de vista conjuntural, as principais economias avançadas, particularmente os EUA, reagiram ao ambiente de menor crescimento e de instabilidade financeira do começo dos anos 2000, por meio de políticas monetárias e fiscais largamente expansionistas. Nos EUA, Greenspan comandou uma redução da FED Fund Rate do patamar de 6,5\% (maio de 2000) ao ano para $1 \%$ (junho de 2003), o que facilitou a digestão dos passivos acumulados no período de euforia anterior, evitando que a ruptura financeira ainda mais grave do que a contração verificada em função da bolha especulativa da Nasdaq e dos escândalos corporativos. Havia um temor de que os problemas do mercado acionário contaminassem, ainda mais, o lado real da economia estadunidense. Por sua vez, a gestão fiscal do novo governo republicano (George W. Bush, 2001-2009) transformou a herança de superávits do governo Clinton (1993-2001) em déficits crescentes, dados os aumentos de gastos e reduções de impostos.

Esta combinação alimentou a continuidade do modelo de simbiose entre EUA e China: por parte do primeiro, o crescimento estava baseado na expansão ainda mais intensa do consumo, com endividamento crescente; do lado do segundo, a acumulação de capital, os ganhos de produtividade e os níveis elevados de poupança contribuíram para 
transformar sua base produtiva em fonte estratégica da oferta mundial de manufaturas. Neste contexto, as economias emergentes, particularmente a China, passaram a responder por parcelas crescentes do PIB mundial e, por conta disso, de sua taxa de variação.

Portanto, o eixo central desta nova ordem global girava em torno dos EUA e da China. ${ }^{2} \mathrm{O}$ primeiro representava o grande mercado consumidor, em última instância, e o segundo, a nova fábrica do mundo. Em contrapartida aos resultados favoráveis daquele ciclo, explicitavam-se vários desequilíbrios, especialmente nos pagamentos internacionais. A economia estadunidense, com seus níveis recordes de endividamento nas esferas privada e pública, apresentavam padrões de gastos domésticos que excediam, de forma preocupante à renda nacional. Por conta disso, ampliavam-se os déficits em conta corrente, que de uma média de $2 \%$ do PIB no final dos anos 1990 , passaram a $4 \%$ no começo dos anos 2000 e atingiram o pico de $6 \%$ a $7 \%$, entre 2006 e 2007. O espelho dos déficits em conta corrente é a utilização de poupança externa para seu financiamento. No caso dos EUA, a absorção de poupança externa entre US\$ 500 bilhões e US\$ 1 trilhão ao ano, ao longo deste ciclo, eram possíveis na medida em que o resto do mundo, especialmente os governos dos países com superávits em conta corrente, passaram a acumular ativos de reserva, também em níveis inéditos. ${ }^{3}$

Tais desequilíbrios nos pagamentos internacionais também provocaram um descolamento entre as posições financeiras. Os EUA, que já possuíam uma posição líquida de investimento deficitária em 1997, equivalente a 3\% do PIB mundial, passaram a ter, em 2008, uma posição devedora líquida de $8 \%$ do PIB mundial. Na outra ponta, velhos - o Japão e os países exportadores de petróleo - e novos credores - a Ásia, liderada pela China - viram-se na situação de ampliação significativa se suas posições. Houve, assim, uma redistribuição do poder e da riqueza em nível mundial, representando na posse de ativos financeiros, a mesma dinâmica de ascensão produtiva e comercial descrita anteriormente.

Neste mesmo ciclo (2003-2008), as regiões periféricas, com exceção do Leste Europeu, experimentaram uma melhoria sensível de seus resultados em conta corrente. A América Latina, usualmente deficitária, apresentou resultados positivos da ordem de $1 \%$ do PIB da região em média, entre 2004 e 2007, voltando a apresentar um déficit de 0,7\% em 2008, ainda assim, um valor moderado diante dos déficits de $4 \%$ do PIB, comuns nos anos 1990. Tal inversão nos resultados em conta corrente contribuiu para o acúmulo de reservas internacionais. No caso

2 Ver Ferguson e Schularick (2007), Unctad (2008, 2009) e BIS (2007; 2008; 2009).

3 Ver El-Erian (2008), Unctad (2008; 2009) e BIS (2008). 
da América Latina, em 2007 e 2008, as principais economias da região tinham reservas da ordem de US $\$ 300$ bilhões - pouco mais de $10 \%$ do PIB regional. Este valor era o triplo do verificado no começo dos anos 2000 , tanto em termos absolutos, quanto relativos à renda. Tendência semelhante de crescimento se verificou na Ásia e, com mais intensidade, no Oriente Médio. Das economias analisadas, somente o Leste Europeu experimentou, no ciclo aqui destacado, o aprofundamento dos déficits em conta corrente, reproduzindo o modelo de crescimento com absorção de poupança externa.

A China merece uma consideração especial, na medida em que seu peso individual nas estatísticas agregadas tende a distorcer a percepção dos dados. Assim como as demais economias asiáticas, o país passou a priorizar, depois da crise financeira de 1997 e 1998, uma estratégia de manutenção de superávits em conta corrente. ${ }^{4}$ Estes ainda situavamse na casa de $2 \%$ do seu PIB até o início do ciclo de forte expansão da economia mundial. Depois de 2003, os resultados positivos não pararam de se expandir (Tabela 1), pelo menos até a eclosão da crise financeira global, e chegaram ao patamar de $11 \%$ do PIB chinês - ou US $\$ 372$ bilhões - no ano de 2007. As reservas internacionais atingiram o montante de mais de US\$2,2 trilhões - ou 46\% do PIB - no ano de 2009. Este boom foi a expressão externa da aceleração do crescimento da economia chinesa que, por sua vez, esteve diretamente associada à ampliação dos já elevados níveis de investimento. Conforme pode ser observado na Tabela 1, os investimentos atingiram uma média de $40 \%$ do PIB entre 2003 e 2009.

Tabela 1 - Indicadores Macroeconômicos Selecionados da China, 1991-2010*

\begin{tabular}{llllllllllll}
\hline I. Fundamentos Macroeconômicos - Taxas Anuais de Crescimento \\
\hline & $\begin{array}{l}\text { 1991- } \\
\text { 2001 }\end{array}$ & $\mathbf{2 0 0 2}$ & $\mathbf{2 0 0 3}$ & $\mathbf{2 0 0 4}$ & $\mathbf{2 0 0 5}$ & $\mathbf{2 0 0 6}$ & $\mathbf{2 0 0 7}$ & $\mathbf{2 0 0 8}$ & $\mathbf{2 0 0 9}$ & $\mathbf{2 0 1 0 ^ { * }}$ \\
\hline PIB (\%) & 9,7 & 9,1 & 10,0 & 10,1 & 10,4 & 11,6 & 13,0 & 9,0 & 8,7 & 7,9 \\
Inflação (\%) & 6,6 & $(0,4)$ & 3,2 & 2,4 & 1,6 & 2,8 & 6,5 & 1,2 & 1,9 & 3,8 \\
Produção Industrial (\%) & 12,9 & 12,7 & 16,7 & 16,2 & 15,9 & 15,4 & 18,5 & 12,9 & 11,1 & 8,6 \\
Investimento (\%) & 12,5 & 15,3 & 20,0 & 15,3 & 16,8 & 14,9 & 12,3 & 10,0 & 7,2 & 9,4 \\
Exportações (\%) & 14,9 & 22,4 & 34,6 & 35,4 & 28,5 & 27,2 & 25,8 & 17,6 & $(16,2)$ & 13,0 \\
Importações (\%) & 13,1 & 21,3 & 39,8 & 35,8 & 17,6 & 19,7 & 20,3 & 18,7 & $(6,5)$ & 17,0 \\
\hline
\end{tabular}

II. Indicadores Selecionados - Investimento, Setor Externo e Situação Fiscal

\begin{tabular}{|c|c|c|c|c|c|c|c|c|c|c|}
\hline Investimentos (\% do PIB) & 38,5 & 36,3 & 39,2 & 40,6 & 41,0 & 40,7 & 40,1 & 41,1 & 43,7 & 41,6 \\
\hline
\end{tabular}

4 Ver Dooley, Folkerts-Landau e Garber (2005). 


\begin{tabular}{|c|c|c|c|c|c|c|c|c|c|c|}
\hline $\begin{array}{l}\text { Conta Corrente } \\
\text { (\% do PIB) }\end{array}$ & 1,7 & 2,4 & 2,8 & 3,5 & 7,0 & 9,0 & 10,7 & 9,6 & 5,2 & 3,5 \\
\hline IDE líquido (US\$ bilhões) & 28 & 50 & 54 & 59 & 61 & 55,1 & 57,0 & 52,4 & 47,0 & 43,9 \\
\hline $\begin{array}{l}\text { Exportações } \\
\text { (US\$ FOB bilhões) }\end{array}$ & 151 & 326 & 438 & 593 & 763 & 970 & 1.220 & 1.435 & 1.202 & 1.358 \\
\hline $\begin{array}{l}\text { Importações } \\
\text { (US\$ CIF bilhões) }\end{array}$ & 128 & 282 & 394 & 534 & 628 & 752 & 905 & 1.074 & 1.004 & 1.175 \\
\hline Reservas (US\$ bilhões) & 95 & 291 & 408 & 619 & 826 & 1.073 & 1.530 & 1.948 & 2.399 & 2.639 \\
\hline $\begin{array}{l}\text { Divida Externa } \\
\text { (US\$ bilhões) }\end{array}$ & 146 & 186 & 209 & 248 & 282 & 323 & 374 & 375 & 383 & 405 \\
\hline $\begin{array}{l}\text { Dívida Externa Líquida } \\
\text { (\% das exp.) }\end{array}$ & 38,0 & $(28,8)$ & $(45,7)$ & $(62,4)$ & $(69,1)$ & $(74,5)$ & $(89,9)$ & $(99,5)$ & $(149,0)$ & $(147,8)$ \\
\hline $\begin{array}{l}\text { Resultado Fiscal } \\
\text { (\% do PIB) }\end{array}$ & $(1,8)$ & $(2,6)$ & $(2,2)$ & $(1,3)$ & $(1,2)$ & $(0,8)$ & 0,6 & $(0,4)$ & $(3,1)$ & $(3,0)$ \\
\hline $\begin{array}{l}\text { Divida Pública } \\
\text { (\% do PIB)** }\end{array}$ & nd & 18,3 & 18,6 & 18,0 & 17,5 & 17,2 & 17,3 & 17,6 & 19,2 & nd \\
\hline
\end{tabular}

Fonte: IFS - IMF e Deutsche Bank Research - Country Infobase (www.dbresearch.com, capturados em 15/10/2009)

$\left(^{*}\right)$ Estimativas 2009 e 2010 do Deutsche Bank Research (em 24/02/2010)

(**) Dados do Banco Mundial - East Asian and Pacific Update, April 2008 e April 2009.

Se, do lado da demanda global, a economia estadunidense representava a principal fonte de dinamismo, alimentada pelo crédito farto e barato e pelo efeito riqueza, do lado da oferta, as redes globalizadas de produção e comércio localizadas na China garantiam a ampliação da oferta de manufaturas a preços baixos. Na verdade, a própria China foi se tornando uma fonte de demanda, cada vez mais importante, particularmente nos segmentos de energia, alimentos e matérias-primas. A forte alta no preço das commodities não se traduziu em inflação, pelo menos até meados de 2007, pois a China, responsável última por aquele movimento, garantiu a manutenção de preços de manufaturas em níveis estáveis ou cadentes. $\mathrm{O}$ aparente milagre do crescimento acelerado e espraiado, com inflação baixa, tem na China o elo explicativo fundamental.

A combinação de aumentos recordes nos preços das commodities, ${ }^{5}$ desde logo potencializados pela especulação em um ambiente de excesso de liquidez e falta de regulação, e estabilidade nos preços industriais, produziu um choque favorável nos termos de intercâmbio dos países

$5 \quad$ Estimativas do FMI (World Economic Outlook, April 2009) sugerem que, entre 1995 e 2008, o preço real do petróleo cresceu $300 \%$, os preços reais das commodities metálicas expandiramse em $57 \%$ e dos alimentos também variaram positivamente em $7 \%$. Em termos nominais, quase todas as commodities, energéticas ou não, apresentaram seus preços recordes no primeiro semestre de 2008. 
em desenvolvimento, particularmente na América Latina e África, o que permitiu a rara combinação de retomada de crescimento, com melhoria nas contas externas e públicas. Completava-se, assim, o quadro da grande moderação. Todavia, a crise financeira iniciada nos EUA também foi produto da globalização financeira, do crédito farto e da ausência de anteparos regulatórios capazes de ordenar o mundo das finanças, criando, no período atual, a contraface da fase anterior. O ciclo excepcionalmente favorável de crescimento metamorfoseou-se na maior crise financeira desde 1929.

Portanto, tornou-se marcante na literatura a visão de que a conjuntura excepcionalmente favorável do ciclo 2003-2008 se deveu, em grande medida, aos estímulos provocados pela ascensão chinesa. As estimativas dos FMI apontam para o fato de que a expansão chinesa respondeu por, no mínimo, um quarto da variação da renda mundial. Tal crescimento é intensivo no consumo de alimentos, água, energia e matérias-primas diversas, cujo fornecimento origina-se, cada vez mais, fora da China. Isto dá, em virtude do intenso processo de urbanização, que vem transferindo 1\% da população de 1,3 bilhão de pessoas do campo para as cidades, anualmente, e de um ritmo frenético de expansão de investimentos que, em termos reais, tem excedido os $20 \%$ ao ano, o que se traduz numa relação investimentos/PIB superior a 40\% (Tabela 1).

Foi neste contexto que se manifestou a profundidade das relações simbióticas entre as economias chinesa e estadunidense. No plano comercial, a China tornou-se o principal parceiro dos EUA. Todavia, a relação bilateral apontava déficits comerciais crescentes, que passaram de uma média de US\$ 54 bilhões entre 1996 e 1999, para mais de US\$ 200 bilhões, depois de 2005. Em contrapartida, a China, através da estratégia de acumulação de reservas e, assim, de compra de títulos do Tesouro dos EUA, passou a ser um dos principais financiadores dos déficits gêmeos da economia estadunidense. ${ }^{6}$ Tal relação complexa de complementaridade alimentou o debate sobre a sustentabilidade dos desequilíbrios globais de pagamentos e do quadro de elevada liquidez e juros reduzidos.

Conforme pode-se observar na Tabela 1, a manutenção de um ritmo acelerado de crescimento, acima de $10 \%$ a.a. no período recente, se dá tendo por base uma elevação significativa do nível dos investimentos - que atingem estonteantes 41\% do PIB em 2008 e 44\% em 2009 - e um recuo das pressões inflacionárias até 2006, especialmente quando se toma por base o decênio anterior. Os resultados das contas externas

6 Ao final de junho de 2009, a China já se tornara o principal credor externo dos EUA, com a propriedade de US\$ 1.464 bilhão somente em títulos públicos ("Report on Foreign Holdings of U.S. Securities at End-June 2009", April, 2010 - http://www.treas.gov/press/releases/tg677. $\mathrm{htm}$. Acesso em agosto de 2010). 
passam a expressar a velocidade da internacionalização chinesa no período pós-entrada na OMC. Depois de 2002, os superávits em conta corrente passam de uma média de $2 \%$ do PIB para 10,7\% do PIB em 2007, 9,6\% em 2008 e 7,2\% em 2009. Em valores correntes, passou-se de US $\$ 30$ bilhões/ano para mais de US $\$ 300$ bilhões/ano, um incremento de dez vezes em pouco mais de cinco anos.

A corrente de comércio no ciclo em questão cresceu 25\% a.a. em média, com as exportações passando US $\$ 266$ bilhões em 2001 para mais de US\$1,4 trilhão em 2008. No mesmo período, as importações avançaram de US $\$ 232$ bilhões para US $\$ 1$ trilhão. Como a conta capital e financeira permaneceu superavitária, não somente pela absorção líquida de mais de US $\$ 60$ bilhões/ano de investimento direto, em média, depois de 2002, mas também pelo influxo de outras modalidades de capitais que a despeito dos controles de capitais passaram a especular, cada vez mais, a favor de um yuan renmimbi forte - o balanço de pagamentos registrou resultados estruturalmente positivos. Estes expressaram-se na acumulação de reservas internacionais sem precedentes - atingindo, em 2007, mais de US $\$ 400$ bilhões de variação anual, com um nível absoluto de US\$1,9 trilhão (em 2008, o que equivalia a 46\% do PIB e, com isso, em uma situação de fortalecimento da solvência externa, capturada pelo indicador de dívida externa líquida (negativa desde 2001) como proporção das exportações.

Com a crise financeira iniciada nos EUA, a China experimentou uma moderação em seu ritmo de crescimento. Depois de experimentar uma expansão da renda na casa dos dois dígitos, entre 2003 e 2007, o PIB cresceu 9\% em 2008 e 2009. Para 2010 projeta-se um PIB crescendo na casa de $9 \%$ a $10 \%$ ao ano. Os dados conjunturais mais recentes vêm reforçando a percepção de que a economia chinesa encontra-se em uma firme trajetória de recuperação, após os impactos negativos da crise, mais intensos entre o último trimestre de 2008 e o primeiro trimestre de 2009, quando o PIB passou de uma expansão sobre o mesmo período do ano anterior, de um ritmo superior a 10\% para algo entre 6\% e 9\%. Após a pior performance em mais de uma década, no primeiro trimestre de 2009, a economia voltou a se expandir em linha com meta governamental no segundo e terceiro trimestres do ano. O estímulo fiscal e a forte expansão do crédito têm contribuído para contrabalançar os efeitos depressivos da queda na demanda mundial por produtos chineses. 


\section{Tendências Recentes de Integração Regional na Ásia}

Os ensaios editados por Arrighi, Hamashita e Selden (2003) são representativos da historiografia recente acerca do impressionante desenvolvimento asiático, cujo fenômeno chinês é a expressão mais recente e, talvez, mais marcante. Todavia, na perspectiva de longo prazo sugerida no livro, o que se observaria nas últimas décadas seria uma retomada de uma posição hierarquicamente superior dos países asiáticos na ordem internacional. Há 500 anos, não havia nada parecido com um sistema mundial capitalista centrado nas potências ocidentais. Dentre os subsistemas então existentes, o asiático, centrado na China, era o mais próspero. Em um horizonte de médio prazo, desde meados do século XIX, o mundo ocidental consolidou sua base de poder econômico, político e militar, em uma conformação especificamente capitalista. A decadência chinesa, o desmonte das relações tributárias entre o Império do Meio e os demais povos asiáticos, e a tentativa de modernização da região, cujo pioneirismo japonês, a partir da Restauração Meiji, é o caso mais bem-sucedido, são pontos marcantes da "grande divergência" entre os mundos oriental, em decadência, e ocidental, em ascensão (POMERANZ, 2000). Neste sentido, as décadas que se seguiram ao "milagre japonês" do pós-guerra, passaram a testemunhar outros "milagres", com esta região reemergindo e, mais recentemente, reintegrando-se.

O dinamismo econômico asiático e o processo de integração regional, longe de serem processos consolidados, têm experimentado marchas e contramarchas. Para efeitos do presente artigo, segue-se a ponderação de Park (2002), Park e Bae (2002), Rana (2002), Unescap (2002), Eichengreen (2002), dentre outros especialistas e insiders, para quem a crise de 1997-1998 marcou um importante ponto de inflexão na economia política asiática. No começo dos anos 1990, depois de adotarem, em maior ou menor grau, processos rápidos e intensos de liberalização e desregulamentação, várias economias na região passaram por um ciclo financeiro marcado pelo excesso de investimentos com endividamento externo de curto prazo. Os maciços influxos de capitais externos alimentaram o boom real e financeiro. O posterior refluxo, em meio a um movimento de pânico com contágio, precipitou a crise. Interrompeu-se o vigoro crescimento que já durava mais de três décadas. Em alguns casos, experimentou-se a primeira queda real de renda em todo o período do pós-guerra. A crise, os pacotes de socorro liderados pelos órgãos multilaterais e suas condicionalidades, e as reformas estruturais, especialmente nos sistemas financeiros e corporativos, marcaram os anos que se seguiram. Nem mesmo a também impressionante e rápida recuperação de algumas economias foi capaz de reverter 
o trauma gerado pela fragilização externa. A busca de reduzir este tipo de vulnerabilidade, minimizando, também, a potencial dependência de apoio dos órgãos oficiais sediados em Washington, tornou-se um elemento decisivo no cálculo político local, com desdobramentos sobre as estratégias macroeconômicas e a busca de maior cooperação nas esferas monetária e financeira.

É bem verdade que, mesmo antes da crise de 1997-1998, era possível notar uma intensificação na integração comercial regional e nos fluxos bilaterais de investimentos. Da mesma forma, nos anos posteriores à crise, a ascensão chinesa tornou-se no elemento central para a aceleração desta dinâmica. Assim, a crise do final dos anos 1990 parece ter tido um efeito potencializador sobre a dimensão institucional da integração, bem como parece ter criados novas agendas, como a da cooperação monetária e financeira, a homogeneização de certos padrões regulatórios, a necessidade de constituição de fontes alternativas de financiamento e de aplicação de excedentes produzidos na região etc.

Portanto, para o caso asiático, cabe sempre reforçar a diferenciação entre dois conceitos que estão inter-relacionados, que, eventualmente, reforçam-se, mas que refletem distintas dimensões da complexa aproximação entre nações, quais sejam, regionalização e regionalismo. $\mathrm{O}$ primeiro refere-se ao processo espontâneo, porque determinado, em grande medida, pelas forças mercado, de ampliação do espaço econômico regional como origem e destino dos fluxos comerciais, financeiros, tecnológicos e de recursos humanos. Neste sentido, não parece haver dúvidas de que as economias asiáticas, particularmente no Leste da Ásia, vêm experimentando um processo veloz de integração. O segundo fenômeno, o regionalismo, está associado à constituição de uma estrutura política e institucional, por meio de acordos diversos e da criação de organismos supranacionais, que tem por objetivo estimular a integração. As duas ideias podem se confundir no tempo e no espaço, dependendo dos processos concretos em análise. Observadores da experiência asiática recente destacam que a regionalização encontra-se em um estágio muito mais avançado do que o regionalismo (PARK, 2002; GILL; KHARAS, 2007; UNCTAD, 2007).

Ademais, enquanto nos anos 1980 e 1990 a regionalização foi comandada pelo processo de internacionalização dos conglomerados japoneses, tendo por trás o apoio do governo do Japão, particularmente pela mobilização de recursos financeiros oficiais na forma de ODA (Official Development Assistance), nos anos 2000, tem-se verificado um quadro mais complexo, agora centrado no hub chinês. Duas outras características se destacam na regionalização asiática: (i) a forte complementaridade entre os fluxos comerciais e de investimento direto externo (IDE), dando 
forma a uma rede regional de produção; e (ii) a recomposição do comércio exterior, com o crescimento dos fluxos intrarregionais, centralizados na China, e perda relativa de importância dos mercados ocidentais. Aqui se deve perceber que está se manifestando a regionalização centrada na China, na medida em que seus vizinhos vão perdendo market-share nos principais mercados extra-regionais, particularmente os EUA, e compensando isso com o aumento das vendas para a China. Por isso mesmo o volume cada vez maior de comércio de componentes no total transacionado entre os países da região. Etapas sucessivas da produção de manufaturas, da extração e processamento as matérias-primas básicas, produção de energia e alimentos (para as populações urbanas) etc., até o controle do core tecnológico e das redes de distribuição, passam por esta divisão regional do trabalho, cujo comando está em disputa.

Para aprofundar estes pontos, pode-se iniciar com um olhar mais agregado sobre alguns dados que evidenciam o rápido avanço na regionalização, especialmente no período que se seguiu às crises financeiras de 1997-1998. Nas últimas duas décadas a região asiática foi a que apresentou os maiores incrementos no comércio intrarregional, aproximando-se, no início do século XXI, dos níveis de integração verificados na Europa (UNCTAD, 2007). O comércio intrarregional predomina, com as principais economias da região direcionando, em média, 55\% de suas exportações e $56 \%$ de suas importações para os vizinhos. Estes dados, referentes ao ano de 2008, implicam um crescimento entre $10 \mathrm{e}$ 13 pontos percentuais com respeito às médias do ano de 1990 (Tabela 2, no Apêndice). Outras medidas de integração comercial apontam nesta mesma direção, onde se destaca o avanço recente no comércio intrarregional, com uma tendência de aproximação dos níveis observados em regiões tidas como mais integradas, como a União Europeia e o Nafta. No plano financeiro é possível observar a importância dos fluxos intrarregionais de IDE, da ampliação de ativos e passivos localmente gerados e da maior correlação entre os preços dos ativos financeiros, especialmente depois da crise financeira de 1997-1998.

Capanelli, Lee e Petri (2009) realizaram um amplo levantamento de indicadores de integração e cooperação regional. Para o ano de 2007, seu indicador de comércio intrarregional, que considera a razão entre o somatório de importações e exportações para dentro da região, com respeito ao total da corrente de comércio, era de $52 \%$ para a Ásia e $58 \%$ para a União Europeia. Para o Nafta, seria de pouco mais de $40 \%$ e, para o Mercosul, de cerca de $20 \%$. Tendo o segundo indicador mais elevado, o caso asiático também destaca-se pela evolução histórica. Nos anos 1950 , este indicador estava na casa dos $20 \%$, tendo atingido $30 \%$ na metade dos anos 1970, 40\% na segunda metade dos anos 1980. Em 
contrapartida, a Europa partia de níveis de comércio intrarregional na casa dos $40 \%$ nos anos 1950, tendo atingido a casa dos $60 \%$ na década de 1970. Por outro lado, os autores não constatam que a intensidade do comércio intrarregional asiático seja particularmente maior que em outras regiões. Os autores encontraram uma medida de intensidade de comércio intrarregional para Ásia, Europa e Nafta, de mesma magnitude. Para estes agrupamentos, o mercado regional era mais importante em cerca de duas vezes mais do que a média do resto do mundo, o que equivale a um indicador ao redor de 2,00.

Para os investimentos externos diretos (IED) e em portfólio, verifica-se tendência semelhante. Em 2003, ano mais recente reportado pelos autores, o IED regional (entradas e saídas) representava $64 \%$ do total para a Ásia e 75\% para a Europa. No caso dos investimentos em portfólio, 9,6\% dos ativos e 11\% dos passivos asiáticos eram formados regionalmente. Trata-se de um avanço sobre 2001, quando tais indicadores eram, respectivamente, de $5,6 \%$ e $10,1 \%$. Todavia, para o caso europeu, encontrava-se, em 2006, 62\% dos ativos e passivos constituídos na região. A correlação entre os preços das ações cotadas nos mercados locais tem crescido na Ásia, quando comparam-se os períodos pré e pós-crise. Assim, entre 1992 e 1998, tal indicador de 0,46, subindo para 0,54 , entre 1999 e 2007. Para este segundo período, o mesmo exercício apontava um índice de correlação de 0,49 no Mercosul, 0,65 na Europa, e 0,69, no Nafta.

Para medir a convergência cíclica, Capanelli, Lee e Petri (2009) utilizaram o método Baxter-King7 para dados do PIB trimestral entre 1983 e 2005. Constataram que as economias asiáticas estão muito mais correlacionadas entre si e, também, com as economias ocidentais mais industrializadas. $\mathrm{Na}$ ausência de dados comparáveis sobre fluxos migratórios, os autores buscaram, nas estatísticas de turismo da Organização Mundial do Turismo, evidências sobre a importância do espaço regional no livre fluxo de pessoas. Também com dados de entradas e saídas, construiu-se um indicador de participação do mercado regional no total dos fluxos de turistas para o período 2000-2006. Verificou-se que os níveis de integração na Ásia estão mais próximos dos verificados no Mercosul, na faixa dos 50\%, do que aqueles observados na Europa e no Nafta, que estão na casa de $60 \%$. Por fim, os autores constatam que os diferenciais de renda per capita vêm caindo de forma mais intensa na Ásia do que em outras regiões em integração, e que há uma proliferação recente de acordos de livre-comércio e de criação e/ou fortalecimento de instituições regionais.

$7 \quad$ O filtro Baxter-King é utilizado para análise de séries de tempo, em que se busca separar os componentes de ciclo e tendência dos dados em questão. 
É nos marcos da nova configuração da estrutura da economia mundial (MADDISON, 2007), determinada pela ascensão chinesa, que se deve compreender o processo de regionalização em curso na Ásia e que, por isso mesmo, marca uma etapa diferenciada daquela verificada até meados dos anos 1990, cuja liderança era eminentemente japonesa. Foi neste início de século XXI que a China se transformou no principal centro dinâmico da Ásia. Cerca de 1/3 das exportações totais dos países asiáticos emergentes - o que exclui o Japão - se destinam para países da mesma região. A China já absorve quase metade daqueles fluxos (WORLD BANK, 2006; GILL; KHARAS, 2007; UNCTAD, 2007; IMF, 2007b). Em contrapartida, entre 1995 e 2005, os Estados Unidos tiveram uma pequena queda na sua participação como mercado de destino para este conjunto de países, passando de $22 \%$ para $20 \%$. Todavia dois aspectos fundamentais, que não ficam evidentes com esses dados gerais, precisam ser destacados: (i) enquanto a China vem ampliando seu market-share nos EUA, os demais países asiáticos vêm perdendo terreno; (ii) $2 / 3$ do total do comércio intrarregional reflete exportações de matérias-primas e componentes industrializados de outros países da região para a China que, por sua vez, está se transformando em centro regional de montagem final para posterior exportação a terceiros mercados, especialmente os EUA. Assim, conforme sugerem os estudos citados anteriormente, o mercado estadunidense tem uma importância nas exportações asiáticas que é bem maior do que sugerem as estatísticas formais de fluxos bilaterais de comércio.

Há uma importante complementaridade entre as estruturas produtiva e comercial da China e os demais países da região. No setor agropecuário, a China é exportadora de produtos temperados para os países da Asean, e importadora de produtos tropicais. Este fato vem garantindo a viabilização do acordo de cooperação que tem por objetivo criar uma área de livre-comércio China-Asean, a ser implementada entre 2010 e 2015. Já os países com estruturas produtivas mais complexas que a China, como Japão, Taiwan e Coreia, vêm se tornando fontes importantes de suprimento de máquinas, equipamentos e componentes diversos que dão sustentação a um ritmo intenso de ampliação dos investimentos no setor produtivo industrial. Capital e tecnologia fluem na forma financeira - via investimento direto externo - ou na importação de equipamentos modernos. Somente quatro economias da região, Hong Kong, Japão, Coreia do Sul e Taiwan, vêm respondendo por cerca de $60 \%$ do IDE absorvido pela China que, por sua vez, responde por $40 \%$ do total de investimento estrangeiro que entra na Ásia. A demanda chinesa por matérias-primas e equipamentos fica evidenciada no fato de suas importações passarem de uma média mensal de US $\$ 20$ bilhões no começo de 2002, para mais 
de US $\$ 50$ bilhões/mês no final de 2004, início de 2005 - valor que segue crescendo para algo em torno de US $\$ 100$ bilhões/mês em 2007 e 2008 (WORLD BANK, 2008). Assim, a China posiciona-se como importadora líquida de insumos e equipamentos mais sofisticados dentro da região, e exportadora líquida de manufaturas para os mercados ocidentais. Por isso mesmo, na média do período 2000-2004, a China, sozinha, respondeu pela absorção de cerca de $11 \%$ do total exportado na região, contra $8 \%$ do Japão (GILL; KHARAS, 2007).

Compara-se ${ }^{8}$ o perfil do comércio exterior chinês entre o começo dos anos 1990 e o dos anos 2000, percebe-se uma rápida convergência com os padrões de especialização previamente alcançados pelas economias mais avançadas da região. Assim, o peso das manufaturas no total exportado passou $79 \%$ para $90 \%$, acima da média do Leste Asiático, $89 \%$, e pouco abaixo do perfil japonês, 93\%. Dentro das manufaturas, a participação dos segmentos mais intensivos em tecnologia merece destaque, com os equipamentos de telecomunicações e escritório avançando de $6 \%$ para $22 \%$, e máquinas e equipamentos elétricos atingindo $10 \%$ ante os $4 \%$ verificados uma década antes. Os indicadores de vantagens comparativas reveladas sugerem que os pesos relativos dos setores industriais mais dinâmicos estão convergindo entre China, Coreia e Japão, ainda que a liderança tecnoprodutiva seja deste último, o que se revela pela capacidade de inovar, controlar os canais de comercialização e, por isso mesmo, ter preços mais elevados. Do ponto de vista das importações chinesas, cabe destacar que os itens de energia e combustíveis experimentaram uma elevação significativa, de 7\% para 14\%. Somando-se os produtos agropecuários, tem-se pouco mais de 1/5 do total importado em insumos primários estratégicos, um mercado de cerca de US $\$ 200$ bilhões no ano de 2007.

A divisão regional do trabalho centrada na China é particularmente evidente no setor de produtos eletrônicos e de alta tecnologia. Entre 1900 e 2005 este grupo de manufaturas passou de 7\% - US $\$ 4$ bilhões - para 37\% - US\$282 bilhões - das exportações totais da China, e de $10 \%$ - US $\$ 5$ bilhões - para 31\% - US\$ 195 bilhões - das importações. Em sua composição, nota-se que os insumos eletrônicos (partes e peças) respondem por $80 \%$ das importações totais dos eletrônicos e produtos high tech originadas em outros países asiáticos, ao passo que os produtos finais somam mais de $50 \%$ das exportações daquela categoria de produtos. Ademais, há uma radical alteração neste perfil ao longo do tempo, pois, no começo dos anos 1990, a China importava bens finais e exportava componentes. O Banco Mundial estima que 55\% das

Valores médios entre 1990-1994 e 2000-2004 estimados por Gill e Kharas (2007). 
exportações da China se originam da dinâmica de processamento de produtos parcialmente produzidos fora do país por empresas multinacionais. Essas exportações processadas dobraram na última década (WORLD BANK, 2006, p. 19-20). Quando se leva em conta esse padrão, percebe-se que o peso dos mercados da Tríade como destino final das economias emergentes da Ásia pode ser significativamente maior do que o sugerido anteriormente. Estimativas apresentadas pelo Banco Mundial sugerem que tal proporção passaria de 36\% para $45 \%$ para o ano de 2005. Outras sugerem o comércio intrarregional seria de $14 \%$ e o extrarregional de $86 \%$. Ainda assim, é importante deixar claro que nenhuma dessas estimativas invalida o fato subjacente de que há um crescente dinamismo dos fluxos de comércio e investimentos que estão tornando a China o polo central do export-drive regional.

Dados estes crescentes vínculos comerciais regionais, a China também vem sendo cada vez mais ativa no processo de constituição de um ambiente institucional mais favorável à promoção da integração regional. Em meados de 2006, havia quase 40 acordos comerciais em negociação na região, muitos deles provocados pela política externa chinesa em sua busca de estabilidade na fonte de suprimentos de insumos estratégicos (GILL; KHARAS, 2007; UNCTAD, 2007). Além disso, o regionalismo em construção na Ásia foi estimulado pela percepção de vulnerabilidade externa provocada pela crise financeira de 1997-1998 (SHIRK, 2007; KURLANTZICK, 2007). Esta pode ser considerada como um divisor de águas na percepção asiática sobre a necessidade de se criar (ou aprofundar) espaços institucionais e instrumentos mais efetivos, capazes de propiciar uma maior cooperação monetária e financeira na região. ${ }^{9}$

Em um primeiro momento, a crise revelou pelo menos dois aspectos até então pouco considerados pelos policymakers: (i) que o efeito-contágio, quer decorrente da já intensa integração econômica regional, quer originado na percepção pouco seletiva dos investidores ocidentais sobre o risco específico de cada país, poderia introduzir fontes adicionais de instabilidade para além da capacidade doméstica de implementar políticas de contenção das crises; e (ii) que os pacotes de socorro financeiro, liderados e implementados pelas instituições multilaterais "sediadas em Washington", poderiam ser o "cavalo de Troia" a invadir a cidadela das estratégias nacionais de modernização e

9 Neste sentido, em 1998 os Ministros de Finanças dos países da Asean assinaram um termo de entendimento que estabeleceu o Processo de Monitoramento do Asean. Em encontros semestrais, realiza-se o acompanhamento conjunto das políticas dos países membros e, por decorrência, do desempenho macroeconômico e social na região. A troca de informações e a coordenação das ações formam a base desta iniciativa. 
desenvolvimento. Não à toa, o Japão foi o primeiro a reagir, propondo a criação de um Fundo Monetário Asiático (FMA). Este país já vinha, desde a segunda metade dos anos 1980, constituindo uma ampla rede regional de produção liderada por seus conglomerados industriais. Os bancos japoneses eram grandes fornecedores de créditos na região, e o governo garantia, na forma de empréstimos oficiais (ODA - Official Development Assistance), recursos, para que os países receptores dos investimentos japoneses pudessem constituir a infraestrutura física capaz de dar competitividade àqueles.

A crise trouxe uma nova oportunidade para o Japão exercer o que, na sua perspectiva, era algo natural, ou seja, a liderança do processo de integração regional. Todavia, a proposta do FMA não avançou. Às evidentes pressões contrárias vindas dos EUA e do FMI, somaram-se desconfianças internas acerca da pretensa liderança japonesa. Por outro lado, a gravidade da crise criou um novo caminho, que se materializou na chamada Iniciativa de Chiang Mai, ${ }^{10} \mathrm{em}$ homenagem à cidade tailandesa que abrigou um encontro entre os países da Asean junto com o Japão, a China e a Coreia do Sul. Ali iniciou-se a estruturação de uma rede de swaps bilaterais de reservas cambiais que, em 2007, foi transformada em um pool compartilhado em uma base multilateral. Mais importante do que a possibilidade de ter uma linha adicional de defesa diante de eventuais novas crises financeiras, o acordo Asean +3 permitiu a ampliação do diálogo sobre a cooperação monetária e financeira regional, bem como de outros aspectos da integração, particularmente o associado à criação de áreas de livre-comércio.

Em paralelo àqueles esforços, os governos nacionais adotaram estratégias mais agressivas de recomposição de reservas internacionais

10 O encontro de maio de 2000 do Asean, ao qual se seguiu o encontro anual do Banco Asiático de Desenvolvimento, marcou o lançamento e detalhamento inicial do que ficou conhecido como Iniciativa de Chiang Mai, um arcabouço que permitiu a expansão do Arranjo de Swap da Asean (ASA), e a criação das bases para o estabelecimento de swaps cambiais bilaterais e acordos de recompra. O ASA fora criado em 1977 (Asean, 1977) com o objetivo de aliviar a escassez temporária de divisas dos Bancos Centrais de Malásia, Indonésia, Tailândia, Cingapura e Filipinas. Em 2000, estendeu-se sua cobertura para todos os países da Asean, além de Coreia, Japão e China (Asean+3). Com o apoio destes três últimos, ampliaram-se os limites para os swaps - de US $\$ 200$ milhões para US $\$ 1$ bilhão - e criou-se uma rede de Acordos Bilaterais de Swap cambial (ABS), que atingiu o montante de US $\$ 75$ bilhões, em meados de 2007. Neste mesmo ano, essa rede passou a ter um caráter multilateral (UNCTAD, 2007). Assim, o arranjo institucional da ICM foi estruturado com o objetivo do provimento de liquidez para os países membros do acordo que estejam enfrentando restrições severas de curto prazo no balanço de pagamentos, de modo a evitar a eclosão de crises financeiras cujo caráter sistêmico tende a afetar o conjunto da região. Neste sentido, a criação de uma rede de acordos bilaterais de swap (ABS) e a expansão do Arranjo de Swap da Asean (ASA) são sementes, na região, da função de emprestador em última instância, típica dos bancos centrais. 
e de estabilização das taxas de câmbio, o que tornava cada vez menos relevante o mecanismo de swaps cambiais nos termos e montantes então definidos. O novo problema que se manifestava era o que fazer com o excesso de poupança, especialmente quando se constatava que esta se direcionava para os mercados financeiros ocidentais. Assim, as novas iniciativas e cooperação financeira do âmbito do Asean +3 foram estruturadas para aprofundar a integração dos mercados financeiros regionais, tornando-os mais seguros e homogêneos, e para criar novos instrumentos financeiros - como os títulos emitidos pelos governos locais em suas próprias moedas - que pudessem melhor o perfil de financiamento dos governos e dos setores com menor acesso aos mercados internacionais - como as empresas de menor porte.

Sob os auspícios do Asia Bond Markets Initiative vem se conformando ações em várias áreas, que vão da uniformização dos padrões contábeis, ao estabelecimento de novas bases estruturais para o funcionamento dos mercados financeiros. Assim, através de um processo de amadurecimento institucional e ajuste no foco das iniciativas criou-se um conjunto de mecanismos de cooperação que visam a "fortalecer o diálogo político, a coordenação e a colaboração nas áreas financeira, monetária e fiscal", mais especificamente há: (i) o Diálogo de Políticas e Análise das Economias, por meio dos encontros periódicos dos Ministros das Finanças busca-se estabelecer um diálogo que permita reduzir os riscos de crise e dê sustentação para as demais iniciativas; (ii) a Iniciativa de Chiang Mai, que congrega mecanismos de apoio financeiro mútuo para financiar desequilíbrios de curto prazo; (iii) a Iniciativa do Mercado de Títulos Asiáticos (Asian Bond Markets Initiative-ABMI); e (iv) o Grupo de Pesquisa do Asean+3, criado em 2003 para aprofundar estudos em torno de três temas fundamentais, quais sejam, liberalização financeira e arranjos de cooperação, desenvolvimento dos mercados de capitais e coordenação política.

É interessante notar que, se em sua origem os esforços de cooperação na área financeira foram liderados pelo Japão, o que gerou resistências diversas, inclusive da própria China. Por outro lado, o relativo enfraquecimento deste item da agenda do regionalismo coincidiu com a crescente ênfase chinesa na constituição de uma base de infraestrutura física - transportes, comunicação etc. - e legal (tratados de livrecomércio) capaz de viabilizar a regionalização em curso que, conforme argumentado até aqui, tem na China seu vetor de destino. Mesmo reconhecendo que no seu nível atual de desenvolvimento tecnológico e produtivo, a China não é capaz, ainda, de liderar a conformação das fronteiras tecnológicas e produtivas, as lideranças chinesas parecem ter clareza de que o país está sendo capaz de, a um só tempo, reproduzir 
as distintas "etapas" caracterizadas no modelo clássico dos "gansos voadores". Ou seja, mesmo explorando as economias de escala e a vastidão do seu mercado de trabalho para avançar nos setores intensivos em mão-de-obra, a China avança, paralelamente nos setores intensivos em tecnologia (GILL; KHARAS, 2007; UNCTAD, 2007; IMF, 2007b). Mais do que manufaturas Made in China, a ascensão pacífica chinesa implicará a emergência de produtos Designed in China, criados, produzidos e comercializados internacionalmente por conglomerados chineses. Assim, uma diferença marcante do "modelo chinês" com respeito aos "milagres asiáticos" precedentes parece ser a imensa capacidade de potencializar os "fatores determinantes do sucesso", bem como reproduzir, a um só tempo, as etapas que nos demais países ocorreram de forma mais dilatada no tempo, ou ainda, de forma regionalizada, mas sob a influência das decisões estratégicas dos conglomerados japoneses. Este último caso foi típico dos gansos de industrialização mais recente, como Malásia, Filipinas, Tailândia e Indonésia.

\section{Considerações Finais}

A crise financeira global afetou as economias asiáticas de forma diferenciada. Os países mais extrovertidos ${ }^{11}$ (Figura 1 do Apêndice) e cujas estruturas produtivas e cujos canais de comercialização eram mais vinculados aos mercados ocidentais experimentaram fortes contrações em seus produtos. Estes foram os casos de Cingapura, Malásia, Vietnã, Tailândia e Taiwan. Economias mais introvertidas como Índia e Indonésia, ou que implementaram políticas contracíclicas robustas, como a China e, em menor extensão, a Coreia do Sul, sofreram menos e/ou se recuperaram de forma mais rápida (Figura 2 do Apêndice). Em geral, as exportações desabaram com a crise (Figura 3 do Apêndice), colocando em xeque o modelo export-oriented. A característica fundamental da maioria das economias asiáticas é a elevada extroversão, caracterizando uma maior dependência das exportações de manufaturas. Esta que sempre foi apontada como uma virtude tornou-se um problema no momento em que as maiores economias do ocidente enfrentam suas piores recessões em mais de seis décadas, e que os canais de crédito se estreitaram tanto que prejudicaram até o financiamento do comércio exterior.

Com a queda pronunciada nas exportações, muitas empresas da região reagiram, inicialmente, por meio do corte investimentos, particularmente em Cingapura, Hong Kong, Taiwan e Coreia do Sul (WORLD

11 Por extroversão e introversão, entende-se aqui o peso do comércio internacional na economia. 
BANK, 2009b). Por isso mesmo, os respectivos produtos daqueles quatro países, também denominados de NICs de primeira geração, apresentaram quedas de dois dígitos no último trimestre de 2008, quando se toma o dado de trimestre contra o trimestre imediatamente anterior. Em termos anualizados, aquelas economias terminaram 2008 crescendo pouco mais de 3\%, revelando uma importante desaceleração.

Das economias em desenvolvimento, a Tailândia apresentou o pior desempenho no imediato pós-crise. Seu PIB caiu $22 \%$ no último trimestre de 2008, em função da contração nas exportações e dos problemas políticos internos. Projeta-se uma queda de cerca de 3\% do PIB em 2009 e uma recuperação moderada a partir de 2010. A crise foi menos intensa na Indonésia, ao passo que a Malásia, com sua forte dependência dos mercados internacionais deverá ter um PIB negativo entre 3\% e 4\% no ano de 2009. Já no Vietnã, a renda em 2009 deverá crescer 3,5\%, o que representa menos da metade do ritmo verificado nos anos anteriores.

Os gastos públicos e investimentos originados dos pacotes de estímulo fiscal, particularmente na China, contribuíram, de forma decisiva, para que, já no segundo semestre de 2009, a região apresentasse sinais claros de retomada. Para o conjunto dos países de renda média, as medidas contracíclicas representarão algo próximo a 3,6\% do PIB (WORLD BANK, 2009a, 2009b), ao passo que o megapacote chinês atinge 12\% do seu PIB. Em decorrência, a situação fiscal corrente dos governos locais deteriorar-se-á, ainda que, na média, a situação da região é confortável. As políticas monetárias foram beneficiadas pelo recuo da inflação, o que permitiu que os Bancos Centrais de China, Malásia, Filipinas, Indonésia e Tailândia afrouxassem os requerimentos de reservas obrigatórias dos bancos comerciais e/ou reduzissem mais agressivamente as taxas básicas de juros.

Na área externa, o ambiente pós-crise deverá ser de moderação dos superávits em conta corrente, o que contribuirá para aliviar os desequilíbrios de pagamentos globais. Ainda assim, a região como um todo manterá sua situação de superávit em conta corrente, algo que se tornou parte da estrutura econômica do período pós-crise financeira de 1997-1998. Neste contexto, os elevados déficits do Vietnã (mais de $10 \%$ do PIB) são uma exceção, caracterizando o estágio atual daquele país de acelerado crescimento com utilização de poupança externa.

A despeito de ser extremamente sintético, este quadro nos sugere que a Ásia não foi capaz de se descolar completamente da crise financeira global. A contração do crédito internacional e a queda no consumo das famílias nos mercados ocidentais produziram efeitos significativos em muitas economias da região. Por outro lado, explicitou-se, com mais intensidade, a capacidade chinesa de exercer um papel de contrapeso 
e motor do crescimento regional. O sucesso de sua estratégia de contenção dos efeitos da crise, lastreada em uma base prévia de elevada solvência externa e fiscal, permitiu que a China seguisse exercendo um papel catalisador da integração.

Este artigo enfatizou o processo de integração regional, especialmente para o período que se seguiu à crise asiática de 1997-1998. Mostrouse que tal episódio ampliou a percepção das lideranças locais sobre a sua mútua dependência e sobre os perigos da dinâmica financeira global, em um contexto de desregulamentação e de maior integração dos mercados. Ao processo espontâneo de integração comercial, agregou-se uma crescente cooperação na área monetária e financeira. Em paralelo, a ascensão da China deu ímpeto e maior profundidade à dinâmica integracionista. A China está no centro da formação da maior área de livre-comércio do planeta, em seu Acordo com os países da Asean. Da mesma forma, dá passos firmes para viabilizar a transformação do Yuan renmimbi em moeda internacional. Empresas da região já estão aceitando o renmimbi em pagamentos internacionais. Nos meses que se seguiram à atual crise, a China fez acordos de swap cambial da ordem de US $\$ 100$ bilhões, para estimular a internacionalização de sua moeda. Seus bancos de fomento estão fazendo buyers credit para estimular a ampliação de novos mercados externos, capazes de compensar a perda de densidade dos tradicionais compradores dos países ocidentais maduros. Também com o intuito de minimizar os impactos da queda nas exportações, a política cambial foi novamente alterada: foi abandonada a lenta e administrada valorização do Yuan. Os demais países da região buscam, cada vez mais, evitar um desalinhamento muito grande entre suas moedas e a moeda chinesa. Por fim, no plano político, as lideranças chinesas têm se posicionado em defesa na conformação de uma nova arquitetura financeira global, em linha com a visão original de Keynes, de criação de uma moeda internacional não conversível.

Estes fatos sugerem que há espaço de novas transformações e avanços na dinâmica regional de integração, especialmente no que se refere à dimensão monetária e financeira. Aprofunda-se a codependência entre as economias locais, com a força de atração gravitacional exercida pela China. Este país mostra sua musculatura financeira e ambições de fazer aquilo que o Japão tentou, mas não conseguiu totalmente, vale dizer, tornar sua moeda a base das transações comerciais e financeiras regionais, com vistas a um processo mais robusto de internacionalização. Para efeitos do presente artigo, pode-se concluir que há elementos suficientes que autorizam a construção da seguinte hipótese de trabalho, que poderá ou não ser comprovada em futuros estudos, qual seja: assim como a crise de 1997-1998 criou as condições políticas e institucionais 
para o avanço da integração regional, a atual crise revela elementos que possibilitam considerar que a China está em vias de se consolidar como a principal liderança econômica e financeira na região. Isto não significa dizer que este país terá capacidade de traduzir seu potencial de liderança financeira em liderança política, aos moldes do papel exercido por Alemanha e França na Europa. Mas sim, de que a dinâmica de integração real, por meio das redes de produção espacialmente localizadas nos núcleos mais dinâmicos do Leste Asiático, e explicitada nos fluxos de comércio e investimento (GILL; KHARAS, 2007; PREMACHANDRA; MENON, 2010), fortalecem a posição chinesa no tabuleiro do poder regional, e reafirmam a Ásia no centro da nova ordem global em gestação neste século XXI.

\section{Referências}

ARRIGHI, G.; HAMASHITA, T.; SELDEN, M. (Ed.). The resurgence of East Asia: 500, 150 and 50 year perspectives. London: Routledge, 2003.

ASIAN DEVELOPMENT BANK - ADB. Emerging Asian regionalism: a partnership for shared prosperity. Manila: Asian Development Bank, 2008.

. The Key Indicators for Asia and the Pacific 2009. Manila: ADB, 2009. Disponível em: < http://www.adb.org/Documents/Books/Key_Indicators/default.asp >. Acesso em 10 out. 2009.

ATHUKORALA, P., KOHPAIBOON, A. Intrarregional trade in East Asia: the decoupling fallacy, crisis, and policy challenge. ADB Working Paper Series, n. 177. Manila: Asian Development Bank, dec. 2009.

BANK FOR INTERNATIONAL SETTLEMENTS - BIS. 77th Annual Report. Basle: BIS, 2007.

. 78th Annual Report. Basle: BIS, 2008.

. 79th Annual Report. Basle: BIS, 2009.

BAXTER, M.; King, R. Measuring business cycles: approximate band-pass filters for economic time series. NBER Working Paper n. 5022, 1995.

BHASKARAN, M.; GHOSH, R. Global economic and financial crisis impact on development Asia and immediate policy implications. Manila: Asian Development Bank, 2010.

CAPANELLI, G.; LEE, J.; PETRI, P. Developing indicators for regional economic integration and cooperation. $A D B$ Working Paper Series on Regional Economic Integration, $\mathrm{n}$. 33. Manila: Asian Development Bank, sep. 2009.

CORPORACIÓN ANDINA DE FOMENTO - CAF. América Latina en el Comercio Global: ganando mercados. Caracas: Corporación Andina de Fomento, 2006.

DOOLEY, M. P.; FOLKERTS-LANDAU, D.; GARBER, P. International financial stability. Deutsche Bank, 2005. Disponível em: <http://econ.ucsc.edu/ $\sim \operatorname{mpd}>$. Acesso em 1 mar. 2007. 
EICHENGREEN, B. Whither monetary and financial cooperation in Asia? PECC Financial Forum Conference "Issues and Prospects for Regional Cooperation for Financial Stability and Development" Honolulu, aug. 2002.

EL-ERIAN, M. When markets collide: investment strategies for age of global economic change. New York: McGraw Hill, 2008.

FERGUSON, N.; SCHULARICK. M. Chimerica and global asset market boom. International Finance, v. 10, n. 3, p. 215-239, 2007.

FRANKEL, J.; ROSE, A. The endogeneity of the optimum currency area criteria. The Economic Journal, v. 108, n. 449, p. 1009-1025, 1998.

GILL, I.; KHARAS, H. An East Asian renaissance: ideas for economic growth. Washington: World Bank, 2007.

GOLDMAN, S. BRICs and beyond. 2007. Disponível em: < http://www2.goldmansachs. com/ideas/brics/BRICs-and-Beyond.html > . Acesso em 5 fev. 2008.

GROSS, B. On the "Course" to a new normal. Investment Outlook, Sep. PIMCO, 2009.

Disponível em: <http://www.pimco.com/LeftNav/Featured+Market+Commentary/ $\mathrm{IO} / 2009 / \mathrm{Gross}+\mathrm{Sept}+$ On + the + Course + to $+\mathrm{a}+\mathrm{New}+$ Normal.htm $>$. Acesso em 10 fev. 2010.

INTERNATIONAL MONETARY - FUND. International Financial Statistics on Line, 2009.

. World Economic Outlook, April. Washington, DC: IMF, 2008a.

. World Economic Outlook, Oct. 2009a. Disponível em http://www.imf.org. Acesso em 10 fev. 2010.

KAWAI, M. Toward a regional exchange rate regime in East Asia. ABD Institute Discussion Paper, n. 68. Tokyo: Asian Development Bank Institute, 2007.

KIM, S., LEE, J.; PARK, C. Emerging Asia: decoupling or recoupling. ADB Working Paper Series on Regional Economic Integration Manila n. 31 Asian Development Bank, jun. 2009.

MADDISON, A. Contours of the world economy, I-2030 AD. Oxford University Press, 2007. . The world economy: a millennial perspective. Paris: OECD, 2001.

McKIBBIN, W. J.; CHANTHAPUN, W. P. Exchange rate regimes in the Asia-Pacific Region and the global financial crisis. $A D B$ Working Paper Series on Regional Economic Integration n. 36 Manila: Asian Development Bank, oct. 2009.

NATIONAL INTELLIGENCE COUNCIL. Global Trends 2025: a transformed world, 2008. Disponível em: < http://www.dni.gov/nic/NIC_2025_project.html > . Acesso em 16 fev. 2010.

. Mapping the global future. 2005. Disponível em: <http:/www.dni.gov/nic/ NIC_2020_project.html>. Acesso em 19 fev. 2010.

NAUGHTON, B. The Chinese economy: transitions and growth. Cambridge: The MIT Press, 2007.

O'NEILL, J. et al. How solid are the BRICs? Global Economic Papers n. 134. Goldman Sachs, 2005. Disponível em: <www.gs.com>. Acesso em 5 fev. 2010.

PARK, Y.; BAE, K. Financial liberalization and economic integration in East Asia. PECC Financial Forum Conference "Issues and Prospects for Regional Cooperation for Financial Stability and Development”, Honolulu, aug. 2002. 
PARK, Y. C. Can East Asia emulate European economic integration? PECC Financial Forum Conference "Issues and Prospects for Regional Cooperation for Financial Stability and Development”, Honolulu, aug. 2002.

POMERANZ, K. The great divergence: China, Europe, and the making of modern world economy. Princeton: Princeton University Press, 2000.

PREMA-CHANDRA, A.; MENON, J. Global production sharing, trade patterns, and determinants of trade flows in East Asia. ADB Working Paper Series on Regional Economic Integration n. 41: Asian Development Bank, jan. 2010.

RANA, P. B. Monetary and financial cooperation in East Asia: the Chiang Mai initiative and beyond. ERD Working Paper n. 6, Manila: Asia Development Bank, 2002.

. Trade intensity and business cycle synchronization: the case of East Asia, ADB Working Paper Series on Regional Economic Integration n. 10: Asian Development Bank, 2007.

SHIN, K.; WANG, Y. Trade integration and business cycle synchronization in East Asia. Asian Economic Papers, v. 2, n. 3, p. 1-20, 2003.w

SPENCE, M. Emerging financial markets after the global financial crisis. PIMCO Viewpoints, aug. 2009. Disponível em: <http://www.pimco.com/LeftNav/Viewpoints/2009/ Emerging+Financial+Markets+Spence+August.htm> . Acesso em 10 fev. 2010.

TOLOUI, R. When capital flows uphill: emerging markets as creditors. PIMCO, 2007. Disponível em www.pimco.com. Acesso em 20 jun. 2007.

UNITED NATIONS CONFERENCE ON TRADE AND DEVELOPMENT - UNCTAD. Trade and Development Report, 2007. Geneva: UNCTD, 2007.

Trade and Development Report, 2008. Geneva: UNCTAD, 2008.

Trade and Development Report, 2009. Geneva: UNCTAD, 2009.

UNITED NATIONS DEVELOPMENT PROGRAM - UNDP. Human Development Report 2009. New York: UNDP, 2009.

UNITED NATIONS ECONOMIC AND SOCIAL COMMISSION FOR ASIA AND PACIFIC UNESCAP. Bulletin on Asia-Pacific Perspectives 2002/2003: sustaining growth amidst uncertainties. Bangkok, 2002. Disponível em: <www.unescap.org>. Acesso em 10 out. 2009.

WILSON, D.; PORUSHOTAMAN, R. Dreaming with BRICs: the path to 2050. Global Economic Papers n. 99: Goldman Sachs, 2003. Disponível em: <www.gs.com>. Acesso em 25 jun. 2007.

WORLD BANK. Global Development Finance 2009. Washington, DC: World Bank, jun. 2009b.

. Global Economic Perspectives 2009. Washington, DC: World Bank, 2009a.

. World Development Indicators, 2009. Washington, DC: World Bank, 2009c.

. World Trade Indicators 2008. mês? Washington, DC: World Bank, 2008.

World Economic Forum. The Global Competitiveness Report 2008-2009.

WORLD TRADE ORGANIZATION - WTO. International Trade Statistics 2008. Geneva: WTO, 2008.

WU JIGLIAN. Understanding and interpreting Chinese economic Reform. Mason: Thomson, 2005. 
Apêndice

Tabela 2 - Destino das Exportações em Economias Selecionadas (\% do total das exportações de mercadorias)

\begin{tabular}{|c|c|c|c|c|c|c|c|c|c|c|c|c|c|c|c|c|}
\hline \multirow{2}{*}{ Destino } & \multicolumn{2}{|c|}{ Ásia } & \multicolumn{2}{|c|}{ Europa } & \multicolumn{2}{|c|}{$\begin{array}{l}\text { Central e } \\
\text { do Norte }\end{array}$} & \multicolumn{2}{|c|}{$\begin{array}{l}\text { Oriente } \\
\text { Médio }\end{array}$} & \multicolumn{2}{|c|}{$\begin{array}{l}\text { América } \\
\text { do Sul }\end{array}$} & \multicolumn{2}{|c|}{ África } & \multicolumn{2}{|c|}{ Oceania } & \multicolumn{2}{|c|}{$\begin{array}{l}\text { Resto do } \\
\text { Mundo }\end{array}$} \\
\hline & 1990 & 2008 & 1990 & 2008 & 1990 & 2008 & 1990 & 2008 & 199 & 2008 & 199 & 2008 & 199 & 2008 & 1990 & 2008 \\
\hline China & 68,3 & 40,3 & 14,7 & 23,7 & 10,0 & & 2,3 & & & & 1,9 & & 0,9 & & 1,5 & 1,9 \\
\hline Cingapura & 47,2 & 66,1 & 17,2 & 10,1 & 23,0 & 10,0 & 2,6 & 2,5 & & & 1,9 & & 4,0 & & 3,8 & \\
\hline $\begin{array}{l}\text { Coreia } \\
\text { do Sul }\end{array}$ & 34,0 & 51,0 & 15,5 & 15,6 & 33,4 & 16,2 & 3,0 & 5,3 & & & 1,4 & & 1,7 & & 10,2 & \\
\hline Filipinas & 34,8 & 67,9 & 18,8 & 11,4 & 40,2 & 14,4 & 1,6 & 1,0 & & & 0,2 & 0,3 & 1,6 & & 2,6 & \\
\hline Hong Kong & 42,4 & 66,8 & 20,2 & 13,6 & 27,2 & 12,8 & 1,6 & 1,7 & 0,5 & & 1,7 & & 1,9 & 1,6 & 4,5 & \\
\hline Índia & 21,0 & 35,4 & 47,2 & 22,7 & 16,3 & 15,2 & 7,1 & 15,8 & & & 1,8 & 5,7 & 1,2 & 1,0 & 5,2 & \\
\hline Indonésia & 64,4 & 63,5 & 12,8 & 12,7 & 13,8 & 10,9 & 3,0 & 3,7 & & & 0,5 & & 1,9 & & 3,4 & \\
\hline Malásia & 58,0 & 60,9 & 16,6 & 11,7 & 18,1 & 15,0 & 2,5 & 3,5 & & & 0,4 & & 2,0 & & 2,2 & \\
\hline Tailândia & 37,9 & 54,7 & 25,3 & 14,9 & 25,3 & 13,2 & 5,4 & 5,4 & 0,2 & & 2,1 & 3,3 & 1,9 & 4,9 & 2,0 & 2,0 \\
\hline Taiwan & 38,2 & 66,3 & 18,2 & 11,7 & 36,0 & 13,9 & 2,1 & 2,2 & 0,6 & 1,7 & 1,9 & 1,1 & 2,3 & 1,7 & 0,6 & 1,3 \\
\hline Vietnã & 39,1 & 39,8 & 48,1 & 20,6 & 0,6 & 22,0 & 0,9 & 0,6 & 0,0 & 0,4 & 0,2 & 0,2 & 0,3 & 8,3 & 10,7 & 8,1 \\
\hline $\begin{array}{l}\text { Média não } \\
\text { ponderada }\end{array}$ & & & 23,2 & 15,3 & 22,2 & 15,1 & 2,9 & 4,2 & 0,3 & 1,4 & 1,3 & 2,0 & 1,8 & 3,3 & 4,2 & 3,0 \\
\hline
\end{tabular}

\begin{tabular}{lllllllllllllllllll}
\hline \multicolumn{10}{l}{ Memória: economias maduras da Ásia-Pacífico } \\
\hline Austrália & 50,6 & 64,4 & 17,1 & 11,4 & 12,9 & 6,6 & 4,5 & 4,1 & 0,7 & 1,1 & 0,6 & 1,9 & 7,6 & 5,6 & 5,9 & 5,0 \\
Japão & 26,1 & 43,9 & 23,0 & 17,1 & 36,2 & 22,3 & 3,4 & 4,7 & 1,1 & 1,8 & 1,6 & 1,4 & 3,1 & 2,7 & 5,4 & 6,0 \\
Nova & 30,3 & 33,0 & 21,6 & 14,3 & 16,8 & 13,5 & 2,7 & 4,9 & 1,0 & 2,4 & 1,4 & 2,7 & 22,1 & 26,2 & 4,0 & 3,0
\end{tabular}

Fonte dos dados primários: http://www.adb.org/Documents/Books/Key_Indicators/2009/ Country.asp. Acesso em fevereiro de 2009.

Tabela 3 - Origem das Importações em Economias Selecionadas (\% do total das importações de mercadorias)

\begin{tabular}{|c|c|c|c|c|c|c|c|c|c|c|c|c|c|c|c|c|}
\hline \multirow{2}{*}{ Origem } & \multicolumn{2}{|c|}{ Ásia } & \multicolumn{2}{|c|}{ Europa } & \multicolumn{2}{|c|}{$\begin{array}{l}\text { Central e } \\
\text { do Norte }\end{array}$} & \multicolumn{2}{|c|}{$\begin{array}{l}\text { Oriente } \\
\text { Médio }\end{array}$} & \multicolumn{2}{|c|}{$\begin{array}{l}\text { América } \\
\text { do Sul }\end{array}$} & \multicolumn{2}{|c|}{ África } & \multicolumn{2}{|c|}{ Oceania } & \multicolumn{2}{|c|}{$\begin{array}{l}\text { Resto do } \\
\text { Mundo }\end{array}$} \\
\hline & 1990 & 2008 & 1990 & 2008 & 1990 & 2008 & 1990 & 2008 & 1990 & 2008 & 199 & 2008 & 199 & 2008 & 199 & 2008 \\
\hline China & 68,3 & 40,3 & 14,7 & 23,7 & 10,0 & 22,0 & 2,3 & 4,4 & 0,4 & 2,9 & 1,9 & 2,9 & 0,9 & 1,8 & 1,5 & 1,9 \\
\hline Cingapura & 47,2 & 66,1 & 17,2 & 10,1 & 23,0 & 10,0 & 2,6 & 2,5 & 0,4 & 0,5 & 1,9 & 1,7 & 4,0 & 5,7 & 3,8 & 3,3 \\
\hline $\begin{array}{l}\text { Coreia } \\
\text { do Sul }\end{array}$ & 34,0 & 51,0 & 15,5 & 15,6 & 33,4 & 16,2 & 3,0 & 5,3 & 0,8 & 2,7 & 1,4 & 2,7 & 1,7 & 2,2 & 10,2 & 4,2 \\
\hline Filipinas & 34,8 & 67,9 & 18,8 & 11,4 & 40,2 & 14,4 & 1,6 & 1,0 & 0,1 & 0,3 & 0,2 & 0,3 & 1,6 & 1,5 & 2,6 & 3,1 \\
\hline Hong Kong & 42,4 & 66,8 & 20,2 & 13,6 & 27,2 & 12,8 & 1,6 & 1,7 & 0,5 & 0,9 & 1,7 & 0,6 & 1,9 & 1,6 & 4,5 & 2,1 \\
\hline Índia & 21,0 & 35,4 & 47,2 & 22,7 & 16,3 & 15,2 & 7,1 & 15,8 & 0,1 & 2,4 & 1,8 & 5,7 & 1,2 & 1,0 & 5,2 & 1,8 \\
\hline
\end{tabular}

(continua...) 
(continuação)

\begin{tabular}{|c|c|c|c|c|c|c|c|c|c|c|c|c|c|c|c|c|}
\hline Indonésia & 64,4 & 63,5 & 12,8 & 12,7 & 13,8 & 10, & 3 & 3,7 & 0,2 & 1,2 & 0,5 & 1,6 & 1,9 & 3,4 & 3,4 & 3,0 \\
\hline Malásia & 58,0 & 60,9 & 16,6 & 11,7 & 18,1 & 15 , & 2 & 3,5 & 0,3 & 0,6 & 0,4 & 1,3 & 2,0 & 4,3 & 2,2 & 2,7 \\
\hline Tailândia & 37,9 & 54,7 & 25,3 & 14,9 & 25,3 & 13, & 5 & 5,4 & 0,2 & 1,7 & 2,1 & 3,3 & 1,9 & 4,9 & 2,0 & 2,0 \\
\hline Taiwan & 38,2 & 66,3 & 18,2 & 11,7 & 36,0 & 13, & 2 & 2,2 & 0,6 & 1,7 & 1,9 & 1,1 & 2,3 & 1,7 & 0,6 & 1,3 \\
\hline Vietnã & 39,1 & 39,8 & 48,1 & 20,6 & 0,6 & 22 , & 0 & 0,6 & 0,0 & 0,4 & 0,2 & 0,2 & 0,3 & 8,3 & 10,7 & 8,1 \\
\hline $\begin{array}{l}\text { Média não } \\
\text { ponderada }\end{array}$ & 44,1 & 55,7 & 23,2 & 15,3 & 22,2 & 15 & 12 & 4,2 & 0,3 & 1,4 & 1,3 & 2,0 & 1,8 & 3,3 & 4,2 & 3,0 \\
\hline \multicolumn{17}{|c|}{ Memória: economias maduras da Ásia-Pacífico } \\
\hline Austrália & 50,6 & 64,4 & 17,1 & 11,4 & 12,9 & 6,6 & 4 & 4,1 & 0,7 & 1,1 & 0,6 & 1,9 & 7,6 & 5,6 & 5,9 & 5,0 \\
\hline Japão & 26,1 & 43,9 & 23,0 & 17,1 & 36,2 & 22 , & 3 & 4,7 & 1,1 & 1,8 & 1,6 & 1,4 & 3,1 & 2,7 & 5,4 & 6,0 \\
\hline $\begin{array}{l}\text { Nova } \\
\text { Zelândia }\end{array}$ & 30,3 & 33,0 & 21,6 & 14,3 & 16,8 & 13, & 2 & 4,9 & 1,0 & 2,4 & 1,4 & 2,7 & 22,1 & 26,2 & 4,0 & 3,0 \\
\hline
\end{tabular}

Fonte dos dados primários: http://www.adb.org/Documents/Books/Key_Indicators/2009/ Country.asp. Acesso em fevereiro de 2010.

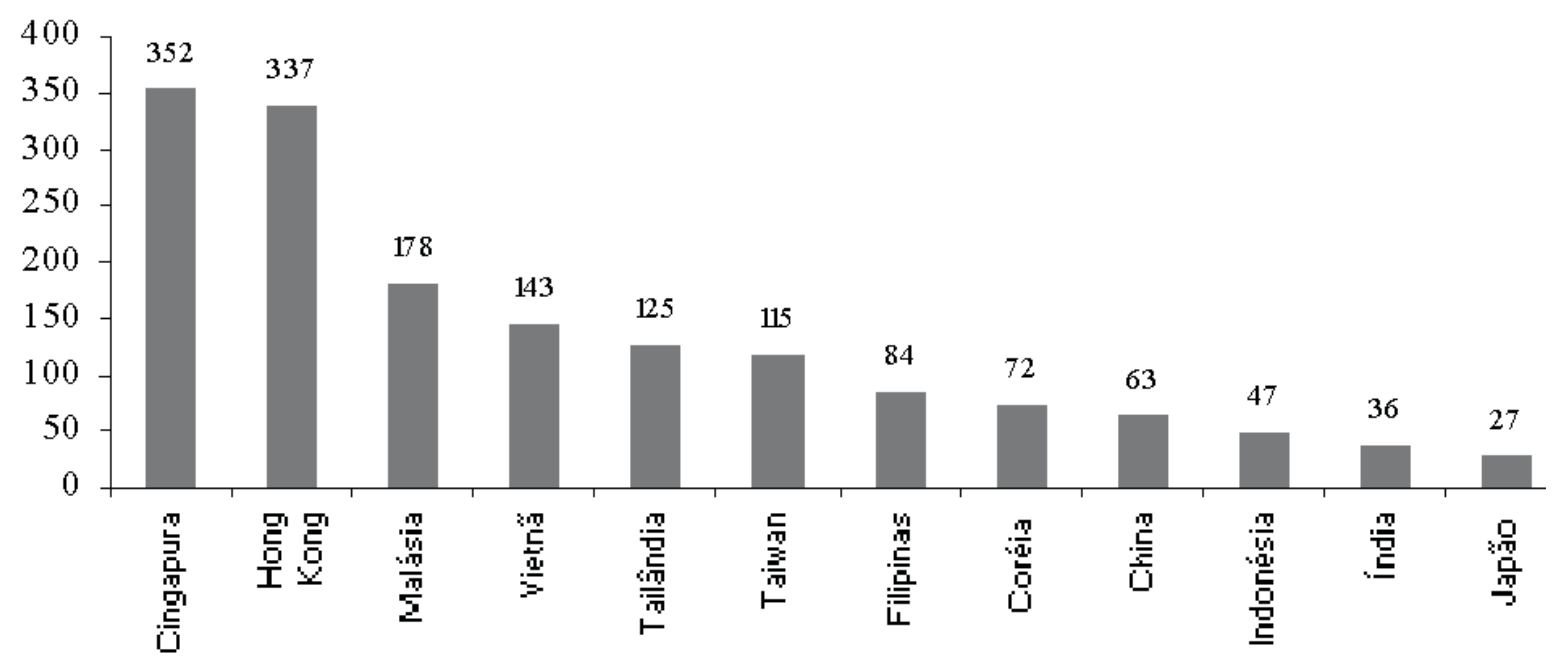

Figura 1 - Grau de Abertura Comercial em Economias Selecionadas (\%, média 2004-2008)*

Fonte dos dados primários: http://www.adb.org/Documents/Books/Key_Indicators/2009/ Country.asp. Acesso em fevereiro de 2009.

(*) Exportações mais importações de bens com a proporção do PIB, em valores correntes. 
(a) Fortemente Extrovertidos

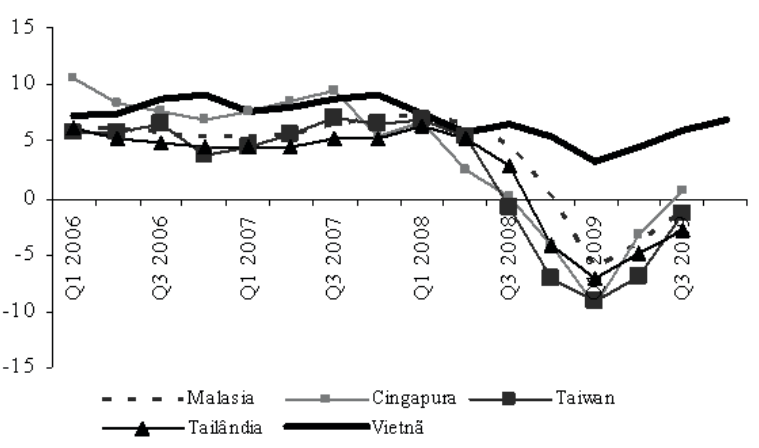

(c) Introvertidos

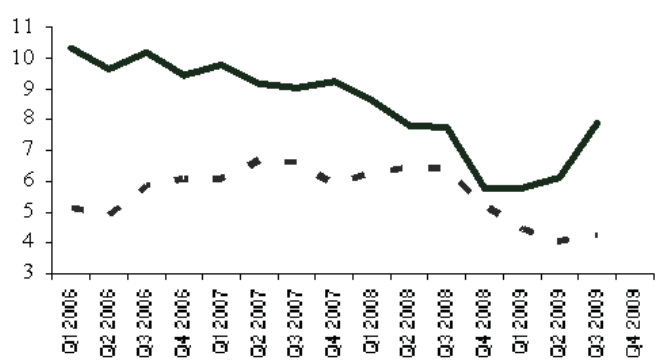

(b) Moderamente Extrovertidas

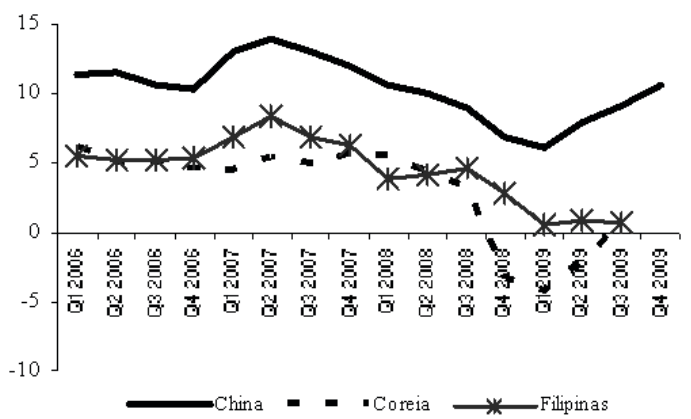

(d) Japão

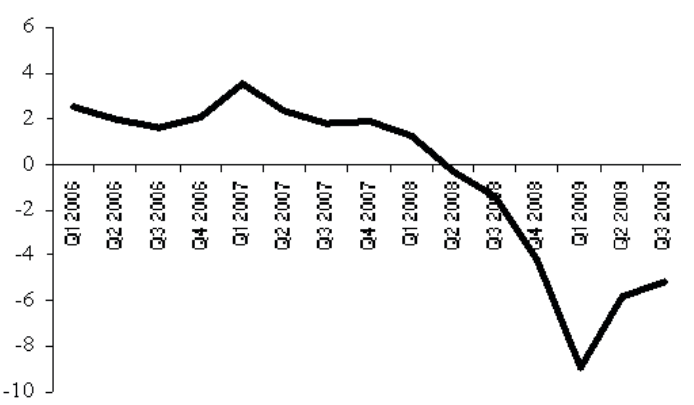

Figura 2 - PIB Trimestral em Economias Asiáticas Selecionadas, 2006-2009 (\% ao ano)

Fonte dos dados primários: http://www.aric.adb.org/aric_database.php. Acesso em fevereiro de 2010. 

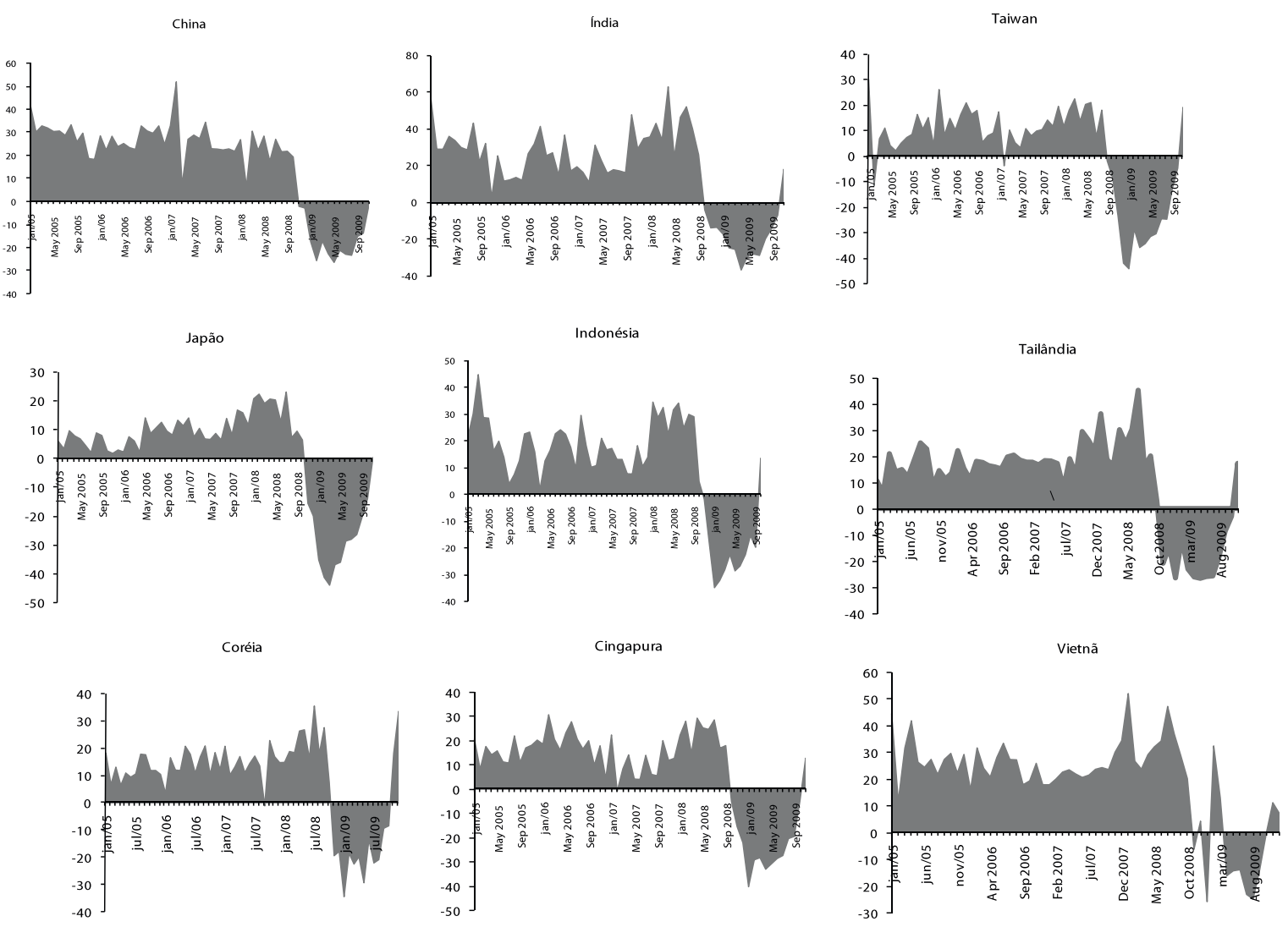

Figura 3 - Taxa de Variação das Exportações de Mercadorias em Economias Selecionadas, 2005-2009 (\% a.a).

Fonte: Elaborado pelo autor.

Recebido: 04/06/2010.

Aceito: 10/08/2010. 